\title{
INNOVATIVE APPROACH TO ASSESSMENT OF PUPILS IN SUBJECT TECHNOLOGY WITH THE USE OF ELECTRONIC INTERACTIVE TASKS
}

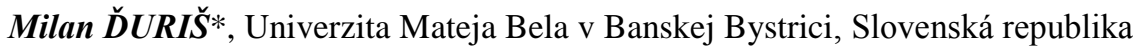
Roman STADTRUCKER, Základná škola s materskou školou Mateja Bela Funtíka v Očovej, Slovenská republika

Přijato: 31. 3. 2016 / Akceptováno: 8. 7. 2016

Typ článku: Teoretická studie

DOI: $10.5507 /$ jtie.2016.022

Abstract: The paper focuses on the analysis of the current trends in e-assessment of pupils in formal education. Emphasis is placed on the application of formative assessment of pupils in cognitive area at repetition and reinforcing of the curriculum in technical subjects with the use of information and communication technologies. For this purpose authors have created a set of electronic interactive tasks for subject Technology in the lower secondary education.

Key words: e-assessment, formative assessment, technical education, set of electronic tasks.

\section{INOVATÍVNY PRÍSTUP HODNOTENIA ŽIAKOV V PREDMETE TECHNIKA S VYUŽITÍM ELEKTRONICKÝCH INTERAKTÍVNYCH ÚLOH}

Resumé: Príspevok sa zameriava na analýzu súčasných trendov elektronického hodnotenia žiakov vo formálnom vzdelávaní. Dôraz je kladený na uplatňovanie formatívneho hodnotenia žiakov v kognitivnej oblasti pri opakovani a upevňovaní učiva $v$ technických predmetoch s využitím informačných a komunikačných technológií. Pre tento účel autori príspevku vytvorili súbor elektronických interaktívnych úloh určený pre predmet Technika v nižšom strednom vzdelávaní.

Klúčové slová: elektronické hodnotenie žiakov, formatívne hodnotenie žiakov, technické vzdelávanie, súbor elektronických úloh.

\footnotetext{
*Autor pre korešpondenciu: Milan.Duris@umb.sk
} 


\section{1 Úvod}

Predkladaná štúdia vymedzuje teoretické východiská a zámer výskumného projektu, ktorý realizujú autori od roku 2013. Výskumný projekt je zameraný na experimentálne overovanie vytvoreného súboru elektronických úloh vo vyučovaní predmetu Technika v nižšom strednom vzdelávaní v Slovenskej republike a na skúmanie vzt’ahu sumatívneho a formatívneho hodnotenia žiakov vo vyučovacom procese.

$\mathrm{V}$ súčasnosti sa $\mathrm{v}$ základných školách najčastejšie stretávame $\mathrm{s}$ uplatňovaním sumatívneho hodnotenia žiakov vo vyučovacom procese (angl. assessment of learning). Tento typ hodnotenia výkonu učebnej činnosti žiaka býva spravidla spojený s jeho klasifikáciou. Formatívne hodnotenie žiakov vo vyučovacom procese (angl. assessment for learning) sa zameriava na získavanie spätnej väzby o progrese $\mathrm{v}$ učení sa žiaka, o nedostatkoch a chybách, $\mathrm{s}$ ciel'om ich odstránenia. Pri tomto type hodnotenia sa nepoužíva klasifikácia žiaka. Ako uvádzajú viacerí autori (Kalaš, 2013, s. 219; Shute a Kim, 2014, s. 314; McMillan et al., 2013, s.1) formatívne hodnotenie žiakov by sa malo používat' vo väčšej miere, pretože zlepšuje kvalitu vedomostí a zručností žiakov, hoci existujú aj kritické analýzy (Dunn, Mulvenon, 2009, s. 1), ktoré poukazujú na nevhodné výskumné metodológie použité na skúmanie formatívneho hodnotenia žiakov, kedy reálne zlepšovanie učebných výsledkov žiakov vo vyučovaní zostáva otázne.

\section{Stratégie elektronického hodnotenia žiakov vo vyučovacom procese}

Informačné a komunikačné technológie môžu byt' aj v procese hodnotenia vel'mi dobrým pomocníkom, pretože zabezpečujú pre učitela podporu pri výkone rutinných činností a zároveň sú aj nástrojom, ktorý umožňuje postupne zhromažd'ovat' informácie o učení sa žiaka, a tak zabezpečit' jeho komplexné hodnotenie. Využitie informačných a komunikačných technológií pre akúkol'vek činnost', ktorá zahŕňa hodnotenie vedomostí, zručností, kompetencií a spôsobilostí môžeme zahrnút' pod pojem elektronické hodnotenie (angl. e-assessment). Jako uvádza Hench (2014, s. 7), pojem e-asssessment sa v odbornej literatúre začal objavovat' od roku 1995. Pred rokom 1995 boli činnosti spojené s výučbou, testovaním a hodnotením s využívaním PC spájané najmä s pojmami „computer aided/assisted“ a „,computer based“. Od roku 2005 sa pojem „e-assessment“ objavuje v odbornej literatúre už pomerne často.

Elektronické hodnotenie žiakov zahŕňa používanie digitálnych zariadení při konštrukcii, distribúcii, ukladaní a vyhodnocovaní učebných úloh, odpovedí, známok alebo spätnej väzby. Tieto zariadenia môžu predstavovat' tradičné desktopové počítače alebo notebooky, prenosné komunikačné zariadenia, ako napr. mobilný telefón, smartphone, digitálne zariadenia, ako napr. PC tablet, iPad alebo elektronické hracie zariadenia. Elektronické hodnotenie môže využívat' vel'ké množstvo formátov, vrátane textových dokumentov a formátu pdf, multimediálne formáty, ako zvuk, video a obrázky, komplexné simulácie alebo didaktické hry. Z hl'adiska organizácia vyučovacieho procesu môže byt' elektronické hodnotenie využívané pri práci v skupinách žiakov alebo ako individuálna samostatná práca žiaka (Crisp, 2011, s. 5).

Hodnotenie žiaka vo vyučovacom procese predstavuje významný prvok v procese učenia sa, obzvláśs' pokial' hovoríme o sebahodnotení žiaka. Výskumy v tejto oblasti potvrdzujú významne pozitívny dopad na zlepšenie výkonu žiaka pri uplatňovaní sebahodnotenia 
s využitím informačných a komunikačných technológií (napr. Wang, 2008; Klecker 2007). Existujú aj výskumy, ktoré nepotvrdili takúto významnost' v konkrétnych podmienkach učenia sa a hodnotenia žiakov (napr. Van der Kleij et al., 2015).

Vývoj a perspektívy hodnotenia žiakov vo vzdelávacom procese $\mathrm{s}$ podporou informačných a komunikačných technológií môžeme z pohl'adu časovej osi naznačit’ ako štyri generácie (Redecker, 2013, s. 3):

1. generácia - 1990 - 2000: vyjadruje automatizovanú administráciu a/alebo skórovanie klasických testov.

2. generácia - 2000 - 2015: vyjadruje používanie testov s výberom odpovede a s krátkou odpoved'ou. Tiež sa začína využívat' adaptívne testovanie, testové úlohy so širšou odpoved'ou, hovoreným slovom a pod. Ide najmä o testovanie na národnej úrovni a o medzinárodné testovania, predovšetkým čitatel'skej gramotnosti a znalosti materinského a cudzieho jazyka. $V$ tomto období sa začínajú tiež objavovat úlohy na riešenie komplexných životných situácí, ktoré sú zamerané na viaceré kl'účové kompetencie žiakov súčasne.

3. generácia - 2015 - 2025: predpokladá sa komplexnejší pohl'ad na problematiku hodnotenia žiakov vo vyučovaní s podporou informačných a komunikačných technológií, pričom jednotlivé učebné úlohy budú zamerané na riešenie problémov, tvorivé myslenie a spoluprácu a rozvoj typických zručností s dôrazom na klúčové kompetencie. Bude sa vyžadovat' aplikácia spolupracujúceho multimediálneho učiaceho prostredia s využitím takých nástrojov ako sú hry, virtuálne svety, virtuálne laboratóriá, simulácie, online spolupráca a pod.

4. generácia - od roku 2025: v procese hodnotenia žiakov sa predpokladá úplná automatická a personalizovaná spätná väzba a inteligentný sprievodca.

Podl'a Redeckera a Johannessena (2013, s. 81), prvé dve generácie elektronického hodnotenia, ktoré môžeme pomenovat' aj ako „Computer-Based Testing“, sú v súčasnosti dominantné. Kl'účovým pojmom je u nich testovanie a používanie PC na zvyšovanie účinnosti testovacích procedúr. Tretia a štvrtá generácia elektronického hodnotenia bezproblémovo integruje holistické a personalizované hodnotenie do učenia. Takéto elektronické hodnotenie (angl. embedded assessment) umožňuje, aby boli učiaci sa priebežne monitorovaní a riadení elektronickým prostredím, ktoré využívajú pri ich vzdelávacích aktivitách, teda zlúčenie sumatívneho a formatívneho hodnotenia do vyučovacieho procesu. Nakoniec, v štvrtej generácii elektronického hodnotenia, vyučovacie a hodnotiace systémy musia byt' schopné poskytovat' okamžitú a validnú spätnú väzbu a informovat' žiakov a učitel’ov týkajúcich sa budúcich vzdelávacích stratégií, založených na individuálnom prístupe a potrebách žiakov.

Zástancovia elektronického testovania a hodnotenia často poukazujú na jeho efektívnost' a výhody, ktoré prináša, napr. nižšie náklady pri opakovaných testoch, redukcia ekologickej a administratívnej zátaže, okamžité vyhodnocovanie testov, ich dostupnost' v l'ubovol'nom mieste a lokalite $\mathrm{s}$ prístupom $\mathrm{k}$ internetu, vysoká miera ich zabezpečenia a pod. Menej sa už hovorí o možnostiach, ktoré prinášajú moderné technológie ako podpora inovácií vo vzdelávaní a rozvoji zručností žiakov pre 21. storočie - riešenie problémov, komunikácia, tímová práca, tvorivost'. Obrázok č. 1 znázorňuje prístup dvoch stratégií pri zmene $\mathrm{z}$ tradičného hodnotenia na hodnotenie elektronické. Ide o stratégiu migrácie tradičného „paper and pencil“" hodnotenia na technologické elektronické hodnotenie a o stratégiu transformácie tradičného hodnotenia na inovatívne elektronické hodnotenie. Pri migrácii 
tradičného hodnotenia na technologické elektronické hodnotenie sa vytvárajú pomocou modernej technológie podmienky pre elektronické hodnotenie, no nedochádza pri tom ku kvalitatívnej zmene tradičného hodnotenia. Príkladom je migrácia „papierového“ testu $\mathrm{s}$ testovými úlohami s výberom odpovede resp. $\mathrm{S}$ tvorbou odpovede na jeho elektronickú formu. Pri transformačnej stratégii ide už o zmenu kvality elektronického hodnotenia, pretože toto inovatívne elektronické hodnotenie ovplyvňuje a podporuje zmeny v obsahu vzdelávania a vo vyučovaní. Ak hovoríme napr. o problémovom vyučovaní, v ktorom sa akcentuje využitie poznatkov v reálnom živote a v ktorom je bežné každodenné využívanie moderných informačných a komunikačných technológií, nedokážeme tieto vedomosti a zručnosti žiaka testovat' a hodnotit' pomocou tradičného ,papierového“ testovania.

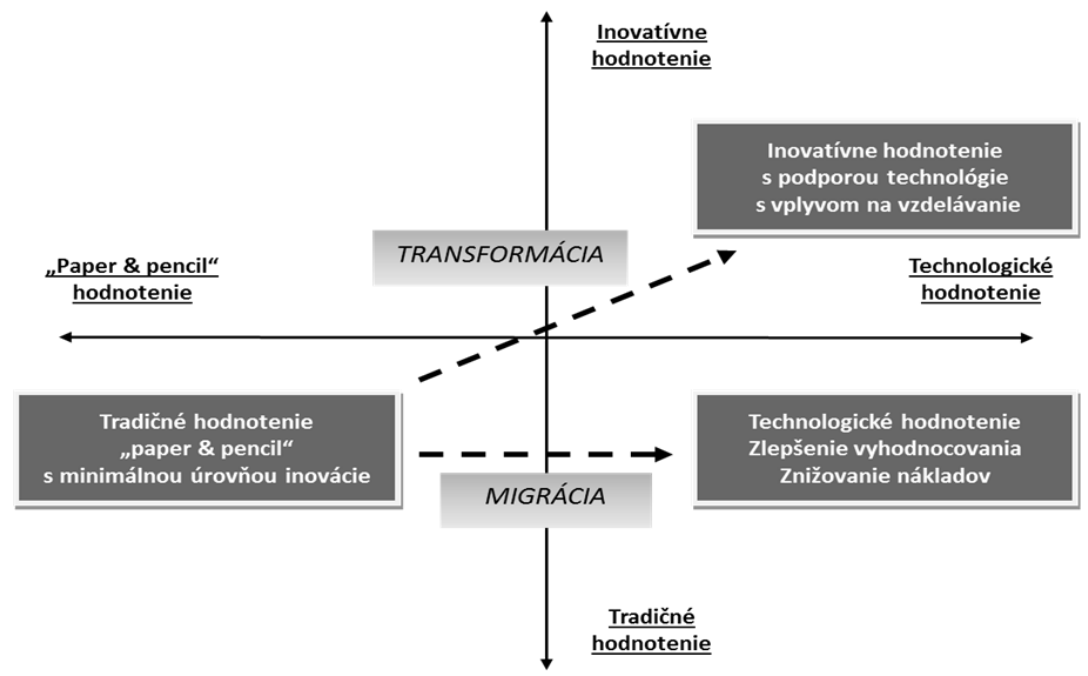

Obr. č. 1: Stratégie hodnotenia žiakov (Ripley, 2009, s. 93)

\section{Učebné úlohy v technickom vzdelávaní a ich elektronická forma}

Učebná úloha sa vo vyučovacom procese používa preto, aby zabezpečila u žiakov dosiahnutie vyučovacieho ciel'a. Je kl’účovým prvkom konštruktivizmu, ktorý dáva do popredia aktívne učenie sa žiaka vo vyučovacom procese. Úloha má žiakov stimulovat', usmerňovat' ich činnost', aby si zopakovali, osvojili a upevnili vedomosti, zručnosti a návyky, rozvíjali schopnosti a utvárali postoje, a aby učitel' zhodnotil postup a výsledok učenia sa žiakov.

Moderné informačné a komunikačné technológie vo vyučovacom procese zaznamenávajú $\mathrm{v}$ súčasnosti svoje uplatnenie aj pri nových podobách učebných materiálov a učebných pomôcok, ktoré obsahujú učebné úlohy alebo sú využívané pri ich riešení. Kalaš et al. (2013, s. 171) v tejto súvislosti rozlišuje nasledovné formy učebných materiálov, ktoré vytvárajú pre žiaka elektronický obsah:

a) textové dokumenty doplnené o obrázky, 
b) hypertextové dokumenty - texty s aktívnymi odkazmi na iné hypertextové dokumenty alebo ich časti,

c) multimediálne kompozície - súbory rôznych multimediálnych foriem obsahu, napr. textu, statických obrázkov, animácií, audio a video záznamov,

d) softvérové nástroje - interaktívne aplety, mikrosvety, modely a prostriedky virtuálnej reality - táto forma prirodzene prerastá do edukačného softvéru, modelovania a simulácií,

e) kombinácia niektorých uvedených foriem.

V predmetoch technického zamerania majú vysoko potenciálne použitie technické animácie a simulácie a 3D projekcia, ktoré môžu byt' aj súčast'ou učebných úloh. Technické animácie a simulácie znázorňujú rôzne činnosti, procesy a procedúry. Ich použitie je vhodné tam, kde nie je dostatočná textová informácia spojená so statickým obrazom. Môžu znázorňovat' napr. funkciu elektronickej súčiastky, elektrotechnického zapojenia, princíp činnosti technického zariadenia a pod.

V odbornej literatúre môžeme nájst' niekol'ko spôsobov kategorizácie inovatívnych úloh pre elektronické hodnotenie žiakov. Sim et al. (2004, s. 218) rozdeluje takéto úlohy do štyroch skupín, a to $\mathrm{v}$ závislosti na spôsobe interakcie medzi žiakom a počítačom:

1. Ukáž a klikni - ide spravidla o úlohy s výberom jednej správnej odpovede.

2. Presuň objekt - ide spravidla o prirad'ovacie a usporiadacie úlohy.

3. Vlož text - ide spravidla o doplňovanie krátkeho textu alebo číselnej hodnoty.

4. Nakresli objekt - žiak kreslí jednoduché objekty alebo čiary.

Boyle a Hutchison (2009, s. 309) uvádzajú tieto vlastnosti elektronickej učebnej úlohy:

a) obsahuje multimediálne obsažné stimulujúce prostredie (grafika, zvuk, video alebo animácia),

b) od riešitel’a úlohy sa vyžaduje interakcia s učebným prostredím rôznymi spôsobmi,

c) majú tendenciu byt' nákladné a časovo náročné na ich vývoj a nie sú jednoduché na tvorbu pre učitel'a.

\section{Zámer a realizácia výskumného projektu - aktuálny stav}

Implementácia moderných informačných a komunikačných technológií do vyučovacieho procesu býva spojená so zmenou tradičných elementov edukácie (obsah, ciele, metódy, formy a pod.) uplatňovaných predovšetkým pri expozícii nového učiva. Často však v tomto smere nie je zohl'adňovaný proces preverovania vedomostí a hodnotenia žiakov, ktorý zostáva nezmenený, prípadne dochádza k modifikácii zauživaných spôsobov hodnotenia žiakov zameraných predovšetkým na sumatívne hodnotenie žiakov vo vyučovacom procese klasifikáciu, kedy klasifikáciu žiaka vhodne dopĺn̆a slovné hodnotenie.

$\mathrm{V}$ rámci pilotáže výskumného projektu sme zrealizovali pedagogický prieskum, ktorý nám poskytol východiská pre d’alšie smerovanie prác na projekte a odbornú prípravu pre ealizáciu pedagogického experimentu. Hlavným ciel'om prieskumu bolo zist'ovat' fakty, názory a postoje učitel’ov predmetu Technika v základných školách v Slovenskej republike, a to v oblasti preverovania vedomostí a hodnotenia žiakov vo vyučovacom procese. Ako výskumnú metódu sme použili anonymný neštandardizovaný dotazník vlastnej konštrukcie, ktorý obsahoval 17 položiek. Položky v dotazníku boli uzavreté, polouzavreté aj otvorené, aby umožnili respondentom vyjadrit' odpovede $\mathrm{v}$ kvantitatívnej i kvalitatívnej podobe. Pedagogický prieskum sme uskutočnili v mesiacoch máj a jún 2014. Náhodným výberom 
sme zo základného súboru stanovili vzorku 100 základných škôl, kam sme zaslali dotazníky poštou. Návratnost' dotazníkov predstavovala $52 \%$. V tabul'ke č. 1 uvádzame základné charakteristiky výberového súboru $(\mathrm{N}=52)$.

\begin{tabular}{|c|c|c|c|c|}
\hline & \multicolumn{2}{|c|}{ Muži } & \multicolumn{2}{c|}{ Ženy } \\
\hline $\begin{array}{c}\text { Dízka pedagogickej praxe } \\
\text { učitel'a }\end{array}$ & $\mathbf{N}$ & $\mathbf{\%}$ & $\mathbf{N}$ & $\mathbf{\%}$ \\
\hline do 5 rokov & 3 & 13,04 & 2 & 6,90 \\
\hline od 6 do 10 rokov & 5 & 21,74 & 1 & 3,45 \\
\hline od 11 do 20 rokov & 8 & 34,78 & 11 & 37,93 \\
\hline od 21 do 30 rokov & 4 & 17,39 & 7 & 24,14 \\
\hline nad 30 rokov & 3 & 13,04 & 8 & 27,59 \\
\hline Celkom & $\mathbf{2 3}$ & $\mathbf{1 0 0 , 0 0}$ & $\mathbf{2 9}$ & $\mathbf{1 0 0 , 0 0}$ \\
\hline
\end{tabular}

Tab. č. 1: Charakteristika vzorky prieskumu

Učitelia predmetu Technika v našom prieskume tak, ako to vyplýva $\mathrm{z}$ grafu č. 1, preferujú praktické a ústne skúšanie žiakov, menej často využívajú písomné práce, didaktické testy a riešenie učebných úloh zameraných na aplikačné a problémové situácie. Vzhl'adom na obsah a ciele predmetu Technika, $v$ ktorom má svoje miesto osvojovanie si elementárnych zručností pri práci s drevom, kovom a plastom, považujeme praktické skúšanie žiakov za najvhodnejšiu formu. Svoje zastúpenie má aj ústne skúšanie žiakov, a to najmä pri preverovaní ich teoretických vedomostí a zručností. Nízke percento pri skúšaní a hodnotení žiakov (písomné práce - 15,38 \%, didaktický test - 14,69\%, riešenie učebných úloh - 13,29 \%) naznačuje, že učitelia venujú vel'mi malú pozornost' uvádzaným spôsobom hodnotenia. Môže to byt' spôsobené nielen charakterom samotného predmetu (praktické zameranie), kde sú uvádzané spôsoby hodnotenia časovo náročné na prípravu, ale i časovou náročnostou na vyhodnotenie samotným učitel'om. Viacnásobne to platí aj pre hodnotenie riešenia učebných úloh, v ktorom práve naopak by mal byt' daný spôsob hodnotenia typickým spôsobom hodnotenia, i ked' si príprava tohto spôsobu vyžaduje od učitel'a nielen dostatok času, ale predovšetkým tvorivý prístup, čo často učitel'om predmetu Technika chýba. 


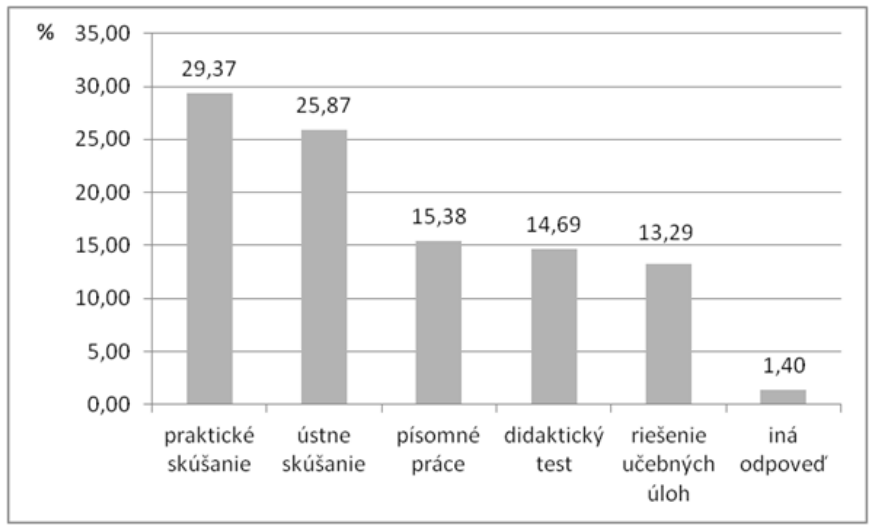

Graf č. 1: Preferencie rôznych metód skúšania a hodnotenia žiakov

Ked’že výstupom realizácie nášho výskumného projektu je súbor elektronických úloh, bolo pre nás dôležité aj zistenie, aký softvér používajú učitelia predmetu Technika pri testovaní žiakov pomocou PC. Väčšina respondentov nepoužíva žiadny softvér $(62,50 \%$ muži a $50 \%$ - ženy). Najdostupnejším a najpoužívanejším je podl'a vyjadrenia respondentov softvérový produkt MS Office - MS Word, MS Excel a MS PowerPoint (16,67 \% - muži a 13,33 \% - ženy), nasleduje používanie aplikácie Hot Potatoes (6,67 \% - ženy), rôzne výučbové $\mathrm{CD}$, ktoré obsahujú aj testové úlohy (6,67 \% - ženy) a portál www.zborovna.sk (6,67 \% - ženy). Respondenti v odpovediach uvádzali aj také softvérové aplikácie, ktoré nie sú primárne určené na testovanie žiakov pomocou PC - MS Office (produkt je určený najmä pre podporu kancelárskych a obchodných činností), portál www.zborovna.sk, portál www.oskole.sk a EduTech portál (ide o zdroj neštandardizovaných didaktických testov prístupných pre učitel'ov) a výučbové CD (predpokladáme, že ich súčast'ou sú aj testové úlohy, ale bez možnosti ich úprav či pridávania nových testových úloh zo strany učitel'a). Funkcionalitu tvorby a administrácie testových úloh obsahujú softvérové produkty Hot Potatoes (aplikácia je určená primárne na testovanie žiakov), Socrative, softvérové aplikácie pre interaktívnu tabul'u a aplikácia Alf. Na základe zistených odpovedí môžeme konštatovat', že učitelia pravdepodobne nevedia, čo sa pod pojmom softvér má rozumiet', a preto sú ich odpovede vel'akrát skresl'ujúce. $Z$ tohto dôvodu treba odpovede učitel'ov považovat' len za orientačné, subjektívne, bez požadovanej validity. 


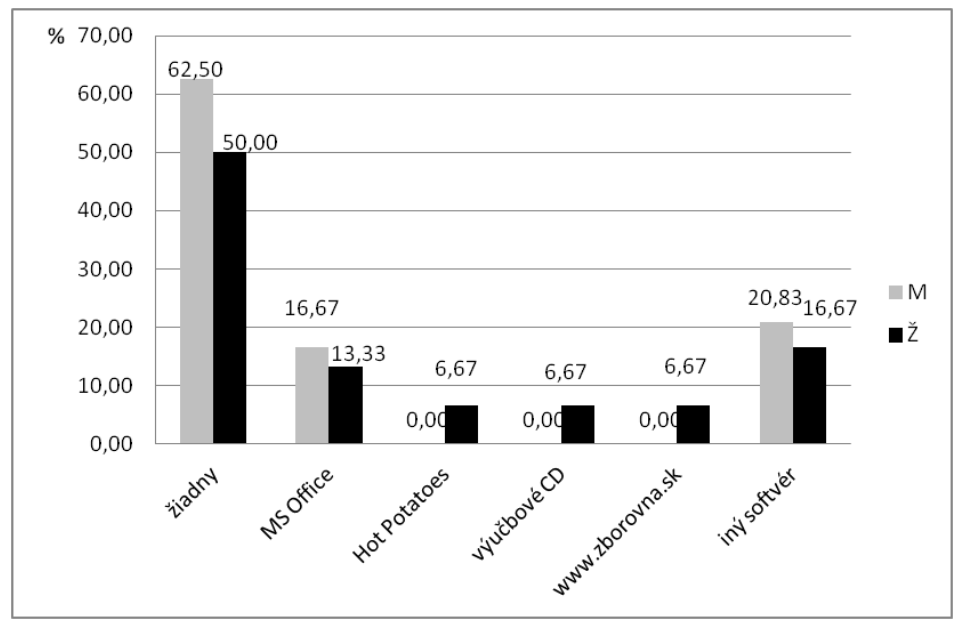

Graf č. 2: Použivanie softvéru pri testovaní žiakov pomocou PC

Z prieskumu d'alej vyplýva, že sebahodnotenie žiakov používajú učitelia predmetu Technika napr. na posúdenie kvality zhotoveného výrobku (jeho celkový vzhl'ad, funkčnost' a pracovný postup pri jeho tvorbe). Pri sebahodnotení žiakov kladú dôraz na rozvoj ich komunikačných zručností, pričom žiaci prezentujú, obhajujú a porovnávajú svoju prácu a jej výsledky aj so spolužiakmi. Žiaci pri sebahodnotení získavajú spätnú väzbu o tom, čo sa naučili, resp. nenaučili a v čom sa majú zlepšit'. Sebahodnotenie podporuje podl'a respondentov aj rozvoj kritického myslenia žiakov. Graf č. 3 nám znázorňuje využitie IKT pri sebahodnotení žiakov vo vyučovacom procese. Informačné a komunikačné technológie nevyužíva až 95,65 \% mužov a 67,74 \% žien z počtu respondentov, ktorí využívajú sebahodnotenie žiakov. Dôvodom je podl’a nášho názoru absencia softvérových nástrojov v jednotlivých školách pre tento typ hodnotenia, nízke povedomie učitel'ov o možnostiach existujúceho softvéru, alebo nevedomost' pri využívaní existujúceho softvéru, ktorý obsahuje aj funkcionalitu okamžitej spätnej väzby, ktorá je dôležitá najmä pri formatívnom hodnotení a sebahodnotení žiakov vo vyučovacom procese. 


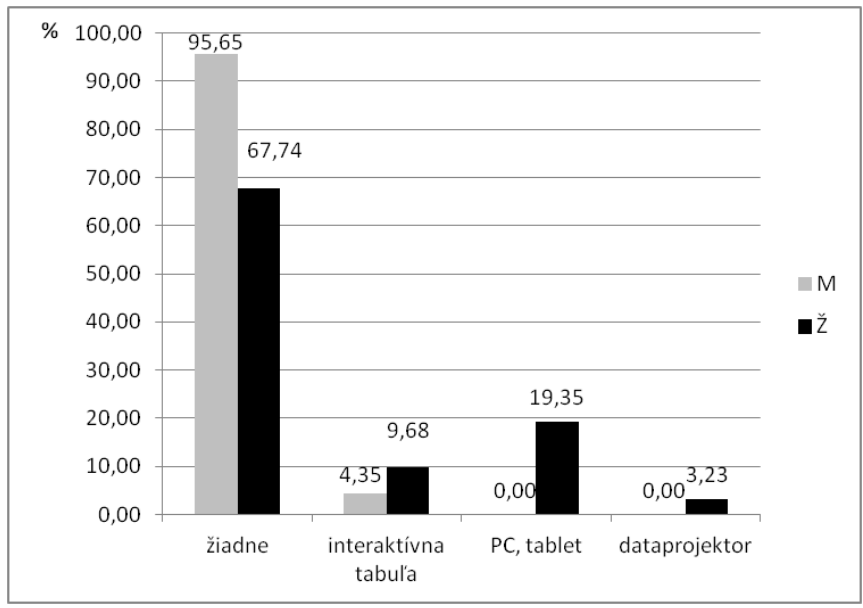

Graf č. 3: Využivanie IKT pri sebahodnotení žiakov

Požiadavka na zvýšenie podielu používania formatívneho hodnotenia a sebahodnotenia vo vyučovacom procese, ako jedného $z$ nástrojov na zlepšenie učenia sa žiakov a ich učebných výsledkov, objavuje sa aj v záveroch a odporúčaniach správy OECD (Shewbridge et al. 2014, s. 143). Správa informuje o analýze vykonanej v oblasti hodnotenia žiakov v školách v Slovenskej republike v roku 2014 a poukazuje na prevládajúce tradičné sumatívne hodnotenie žiakov a nesystematické a zo strany žiakov, učitel'ov a rodičov nepochopené a minimálne používané formatívne hodnotenie žiakov vo vyučovaní.

Náš výskumný projekt, ktorého realizácia začala v roku 2013 a v súčasnosti prebieha jeho d'alšia etapa - realizácia prirodzeného pedagogického experimentu, je zameraný na skúmanie uplatňovania formatívneho hodnotenia žiakov vo fáze fixačnej a aplikačnej pomocou nami vytvoreného súboru elektronických úloh. Základná výskumná otázka znie, či aplikácia formatívneho hodnotenia žiakov vo vyučovaní predmetu Technika v nižšom strednom vzdelávaní pomocou tohto súboru ovplyvní učebné výsledky žiakov so zameraním na kognitívnu oblast' (kvantitatívna stránka) a zároveň kvalitu formatívneho hodnotenia žiakov v technickom vzdelávaní. Nami vytvorený súbor elektronických úloh z pohl'adu technologického integruje softvérovú aplikáciu na testovanie žiakov (QuizCreator) a grafické a multimediálne prvky a simulácie a z pohl'adu didaktického skúšanie a hodnotenie žiakov s ich učením sa. Tým vzniká komplexný softvérový a didaktický nástroj pre elektronické hodnotenie žiaka vo vyučovacom procese.

Experimentálne overovaný súbor elektronických úloh pozostáva zo 14 testových úloh obsahovo zameraných na tému Jednoduché elektrické obvody, ktorá sa vyučuje v 8. ročníku základnej školy v predmete Technika. Súčast'ou každej úlohy je grafický alebo multimediálny prvok alebo simulácia, s ktorou žiak pracuje počas riešenia úlohy pri opakovaní a upevňovaní si svojich vedomostí na vyučovacej hodine. Hoci aplikácia 
umožňuje tvorbu rôznych typov testových úloh, my sme zvolil testové úlohy s výberom odpovede zo štyroch možností. Aplikácia je nastavená tak, že poskytuje žiakovi okamžitú spätnú väzbu o chybe resp. správnosti riešenia danej úlohy. Pokial žiak na otázku odpovie nesprávane, má možnost' celkovo 4-krát riešit' konkrétnu úlohu, až pokial' nie je jeho odpoved' správna. Jednotlivé úlohy súboru sú zamerané na tri úrovne Niemierkovej taxonómie vzdelávacích ciel’ov v kognitívnej oblasti: porozumenie poznatkov, špecifický transfer a nešpecifický transfer.

V rámci prípravy súboru elektronických úloh bola autormi vytvorená banka úloh, ktorá bola zameraná na celý tematický okruh Elektrická energia, ktorý sa vyučuje v 8. ročníku základnej školy v predmete Technika. Na základe aplikácie súboru vo vyučovaní v základnej škole sme realizovali úpravu jednotlivých úloh tak, aby sa tieto vyznačovali primeranou obt'ažnost'ou, zrozumitel'nost'ou, prehl'adnost'ou a obsahovou validitou. Výsledkom tejto činnosti je zostavený súbor elektronických úloh pre vyššie uvedenú tému, v rámci ktorej sa predmetný súbor $\mathrm{v}$ súčasnosti experimentálne overuje na vybraných školách Banskobystrického samosprávneho kraja. Súbor elektronických úloh je dostupný na adrese: http://www.zsocova.edu.sk/quiz.html.

Vo výskumnom projekte overovania súboru elektronických úloh a skúmania vzt’ahu sumatívneho a formatívneho hodnotenia žiakov sme zvolili kvantitatívno-kvalitatívnu stratégiu empirického výskumu, ktorý využíva ako hlavnú výskumnú metódu prirodzený pedagogický experiment. Pomocnými výskumnými metódami sú didaktický test (pretest a posttest) a postojový dotazník pre žiakov pracujúcich so súborom elektronických úloh. Kvantitatívno-kvalitatívne charakteristiky formatívneho hodnotenia žiakov skúmame pomocou obsahovej analýzy automonitorovacieho protokolu, ktorý vypíňa žiak priebežne pri riešení súboru elektronických úloh pod kontrolou učitela a výskumníka.

\section{Záver}

$\mathrm{V}$ súčasnosti sú učitelom technických predmetov $\mathrm{k}$ dispozícii, a to najmä na internetových stránkach, elektronické testy pre potreby skúšania a hodnotenia žiakov vo vyučovacom procese. $\mathrm{Na}$ základe skúseností autorov predkladaného príspevku a vykonaného prieskumu v rámci pilotáže, môžeme konštatovat', že ide vo väčšej miere o testy rôznej kvality a ich uplatnenie je najmä ako nástroj sumatívneho hodnotenia žiakov vo vyučovacom procese. Hodnotenie v modernej škole musí smerovat' $\mathrm{k}$ motivácii žiakov, eliminácii stresu zo skúšania a $\mathrm{k}$ získaniu kompetencií pre sebahodnotenie a sebareflexiu žiaka aplikovaných v reálnom živote. 


\section{Literatúra}

Boyle, A., \& Hutchison, D. (2009). Sophisticated tasks in e-assessment: what are they and what are their benefits? Assessment \& Evaluation in Higher Education [online]. 34(3) [cit. 2014-03-01]. Dostupné z WWW:

http://www.tandfonline.com/doi/pdf/10.1080/02602930801956034.

Crisp, G. (2011). Teacher's Handbook on e-Assessment [online]. [cit. 2013-11-30]. Dostupné z WWW:

http://www.transformingassessment.com/moodle/file.php/84/Handbook_for_teachers.pdf.

Dunn, K. E., \& Mulvenon, S. W. (2009). A Critical Review of Research on Formative Assessment: The Limited Scientific Evidence of the Impact of Formative Assessment in Education. Practical Assessment, Research \& Evaluation [online]. 14(7) [cit. 2015-07-05]. Dostupné z WWW: http://pareonline.net/getvn.asp?v=14\&n=7.

Hench, T. (2014). E-assessment: Past, Present and Future. International Journal of eAssessment [online]. 1(1) [cit. 2014-08-22]. Dostupné z WWW: http://journals.sfu.ca/ijea/index.php/journal/article/viewFile/64/66.

Kalaš, I. et al. (2013). Premeny školy v digitálnom veku. Bratislava: SPN - Mladé letá.

Klecker, B. M. (2007). The Impact of Formative Feedback on Student Learning in an Online Classroom. Journal of Instructional Psychology. [online]. 34(3) [cit. 2016-03-03]. Dostupné z WWW:https://www.learntechlib.org/p/99806/.

McMillan, J. H., Venable, J. C., \& Verier, D. (2013). Studies of the Effect of Formative Assessment on Student Achievment: So Much More is Needed. Practical Assessment, Research \& Evaluation. [online]. 18(2) [cit. 2015-08-08]. Dostupné z WWW: http://pareonline.net/getvn.asp?v=18\&n=2.

Redecker, Ch. (2013). The Use of ICT for the Assessment of Key Competences [online]. [cit. 2013-10-10]. Dostupné z WWW: http://boletines.prisadigital.com/JRC76971.pdf.

Redecker, Ch., \& Johannessenn, Ø. (2013). Changing Assessment - Towards New Assessment Paradigm Using ICT. European Journal of Education [online]. 48(1) [cit. 201408-20]. Dostupné z WWW: http://onlinelibrary.wiley.com/doi/10.1111/ejed.12018/pdf.

Ripley, M. (2009). Transformational Computer-based Testing [online]. In The Transition to Computer-Based Assessment. [cit. 2014-08-15]. Dostupné z WWW:

http://www.gesci.org/assets/files/reporttransition.pdf.

Shewbridge, C. et al. (2014). OECD Reviews of Evaluation and Assessment in Education: the Slovak Republic 2014. [online]. OECD Publishing, 2014. [cit. 2016-05-25]. Dostupné z WWW: http://www.oecd-ilibrary.org/education/oecd-reviews-of-evaluation-andassessment-in-education-slovak-republic-2012_9789264117044-en.

Shute, V. J., \& Kim Y. J. (2014). Formative and stealth assessment. New York: Springer.

Sim, G., Holifield, P., \& Brown, M. (2004). Implementation of computer assisted assesment: lessons from the literature. Research in Learning Technology [online]. 12(3) [cit. 2013-1220]. Dostupné z WWW:

http://www.researchinlearningtechnology.net/index.php/rlt/article/download/11255/12948.

Van Der Kleij, F. M., Feskens, R. C. W., \& Eggen, T. J. H. M. (2015). Effects of feedback in a computer-based learning environment on students' learning outcomes: A meta-analysis. Review of Educational Research [online]. 85(4) [cit. 2016-03-03]. Dostupné z WWW: http://doi:10.3102/0034654314564881. 
Wang, T. (2008). Web-based quiz-game-like formative assessment: Development and evaluation. Computers \& Education [online]. 51(3) [cit. 2016-03-03]. Dostupné z WWW: http://www.sciencedirect.com/science/article/pii/S0360131507001467. 